\title{
Variation Rate of the Value Sense of English Language the Sasak People in the Village Gereneng Subdistrict East Sakra
}

\author{
Mudarman $^{1 *}$, Lalu Mas'ud ${ }^{1}$, Muh. Jaelani Al-Pansori ${ }^{1}$ \\ ${ }^{1}$ Department of English Language Education, Universitas Hamzanwadi \\ Jalan TGLH. Muhammad Zainuddin Abdul Majid no 132, Pancor, Selong, Lombok Timur, Indonesia \\ "Corresponding author. Email: mudarman@gmail.com
}

\begin{abstract}
This Research is a sociolinguistic study aimed to describe the form of variations in the level of language on the value of a sense of language in society Gereneng Sasak village District of East Sakra. Collecting data used observation, interview, and documentation. Analysis of the data used a unified method ekstralingual. These results indicate that a) language Sasak has a very strategic position as a communication tool and unifying role in society of Sasak, b) in addition to functioning as a communication tool, Sasak can also be used as a means of regulating the harmonious relationship within a community and as a filter for the negative impact of advances in science and technology as well as development of the transformation information, and c) use of language Sasak lies in the use of communicative language and maintain the unity of meaning and information by sticking to the principles of language which was based on the identity of the people of Sasak by promoting the value of a sense of language, mutual respect, and civility in relationships.
\end{abstract}

Keywords: Variation language, value sense of language, sasak, sociolinguistics

\section{INTRODUCTION}

Language as a means of communication and social behavior (social behavior) used in communication because society is composed of individuals as a whole and the individual interplay and interdependence. Language as belonging to the community is also stored within each individual. Language is often also regarded as a product of social and cultural products, even an integral part of the culture.

Language is a communication tool used by humans with other community members, who form the idea of ideas, thoughts, wish, or the feelings of the speaker so that what is considered acceptable by hearning or one to talk to, let the language that is used to support the intention or thoughts and feelings of the speaker clearly (Putrayasa, 2010; Rabiah, 2018)

The whole symbolic in mini-style is basically the language. Meanwhile, the language as a symbol, meaning that every sentence and word of course there is symbolized in the form of sound (Adiono, Irsyadi, Hidayat, \& Irawan, 2009).

The language is a phoneme system, which is formed from the sound distinctive features, system morpheme and syntactic. To reveal the meaning of language should relate to the outside world. What is meant by the outside world is the world outside languages including the world in language speakers. The world in such a sense is called reality (Giyoto, 2013). Language is a language that can be adopted as a code received socially or conventional system to convey concepts through the use of desired symbols and combinations of symbols governed by provisions (Harmoko, 2015; Hartanto et al., 2014).

Then, variation or diversity of languages there are two views. First, variation or diversity of languages was seen as a result of their social diversity and the diversity of language speakers of the language function. If the speakers it is a homogeneous group, whether ethnic, social status and field work, the variety or diversity it has nothing in it, it becomes a uniform language. Second, variations or ragama language that already exists to fulfill its function as a means of interaction in diverse community activities. Variation or diversity of languages that can be classified based on the presence of social diversity and function, activity in social community (Rohmadi, 2011; Siandiko, 2018; Nasution, 2019).

Furthermore, variations Sociolect language or social dialects, are the language variations relating to the status, class, and social class of the speakers. This variation concerns all the speakers personal problems, 
such as age, education, sex, occupation, level of nobility, socio-economic circumstances and so on (Sastratmaja, 2013; Hastuti, 2016; Istiqomah, 2017; Astuti, 2018).

Values sense of language is closely related to aspects of meaning in the semantics, there are four things, namely: 1) the sense (sense), 2) the value of sense (feeling), 3) tone (tone), 4) Purpose (intention). Aspects of these meanings certainly have an influence on the kinds of meanings in the semantic, namely: a) The meaning of Emotive, b) connotative meanings, c) Meaning of Cognitive, d) referential meaning, e) meaning Piktorikal (Kuswoyo, 2015; Rohmiatun, 2018; Sandi et al., 2018).

Basically, the value of a sense of language is a form of language that is delivered in the form of words and has a value of sense to the user and have an impact, a certain effect or a certain impression of the user and the meaning of language is a form of language that should be analyzed within the boundaries of the critical elements situations where speakers say it. The meaning of the relationship between language with beyond language agreed upon by the speakers so that mutually intelligible. Limitation on the definition of the meaning is very difficult to determine because each user's language ability and a different perspective on the meaning of a speech or word.

Sasak language is the language used in specialized and general communication by people of Lombok. Sasak language is the first language by most people of Lombok. their first language is the language of his own area, as well as the Sasak language is the first language or the language of the area Mothers in Lombok.

East Sakra society have variations in language and belong to the aristocratic society that uses language class that is Sasak ordinary, middle, and high. Coating system or a community language classes are always in accordance with its social coating system can be expressed several reasons: (1) The quality factor, intelligence, and expertise; (2) The difference in the level of age; (3) The offspring; (4) The influence and power; (5) Position / rank; (6) Wealth. So that this situation will certainly lead to variations or levels or language classes. Therefore, this study aimed to describe the shape variations of the language level of the value of a sense of language in society GerenengSasak village District of East Sakra.

\section{METHOD}

This Research was a qualitative descriptive study with case study model. Berasar source research data from informants who captured using stratified random sampling technique. Data collection was done by combining engineering and technical competent sosiolingistik. The collected data was then selected and analyzed using techniques frontier with frontier ekstralingual as the basic technique for determining the relationship of language and external factors that affect the use of language in varying levels of language on the value of the language sense of community Gereneng Sasak village, District East Sakra. The stages in the data analysis were (1) data reduction stage (data reduction), the act of selecting data in accordance with the object of study in research; (2) the stage of presentation of data (data display), which is preparing the information or data regularly and detailed to be easily understood and analyzed; and (3) the stage of inference (drawing conclusion), the act of preparing the conclusion of the data already acquired.

\section{Results and Discussion Data description}

Sakra Community Center has a variety of language and nobility taking classified community that is Sasak language class ordinary, middle, and high. When viewed from the angle of language, Sakra Village Center has a variety of language and belong to the aristocratic society that uses language class that is Sasak ordinary, middle, and high. So that this situation will certainly lead to variations or levels or language classes.

Examples of the use of language Sasak based levels, as follows:

\section{The Regent has come}

Pak Bupati uah dateng (Rough)

Pak Bupati uah dateng (Ordinary)

Pak Bupati sampun rauh (Soft)

Pak Bupati sampun rauh (Great)

Social Stratification Sasak people.

Sasak tribe known several community groups (social stratification) based on: a) Wisdom; b) Courage; c) Greatness of dharma; dan d) The origin or ancestry. In outline they are divided into: 1) Menak; 2)

Prawangsa; 3) Kaula; dan 4) Panjak (slave).

The feudal class descended from kings and leaders or rulers in ancient times. They are divided into several groups each with a title of nobility.

The highest class is King (Datu) with a degree

For men $\quad:$ Neneq Laki

for women : Neneq Bini

If it has a son neneq man called Pemban. Bini Neneq (nenek) when has a son she was called by her son Inaq, but there is also called Mamiq Bini or Meme. The main nobility with the title:

For men : Raden Nuna (when young) and when he has a son called a Raden

For women : Dinda (when young) and when she has a son called Mamiq Bini or Meme.

Ordinary nobility with the title:

For men : Lalu (if young) and when he has a son called Mamiq. 
for women $\quad$ : Lale or Baiq (when young) and when she has a son called Mamiq Bini (wanita) or Mame (laki-laki).

Someone from the class of Kaula or Prawangsa because of his peculiarity, for example because of his courage, cleverness can be the Menak class. Menak were called Menak Keperdanan. The second group of Sasak tribe is Prawangsa. A group between Menak and Kaula. This class of people come from the lower-level leaders or guards in the days of empire. That is, those who because of his courage and prowess who has a very close relationship with the king. The Prawangsa class is derived from the marriage between Menak class with a slave woman, so that children become Prawangsa. Group underneath is the most independent people. While Panjak are descendants of those who because of fate made the spoils of a war. It can also be due to a fault in the village and he took refuge in a ruler who then make them as panjak.

Social Stratification Language In Society Sasak

As outlined at the beginning of that culture are very concerned on Sasak social relationships between people, manners in public life requires a good and harmonious substitutions in accordance with the existing social status in society khsusunyaSasak village Sakra closely linked to the Center: 1) Age; 2) Social status; 3) Status in family; dan 4) Familiarity.

As a community that is very thick with the rules and manners in the association, the relationship between individuals in a society of Sasak is maintained harmony by promoting ethical conduct in all aspects of life, including the rules of good language adan correctly according to the norms of society with emphasis on politeness

Politeness is closely related to the value of flavor in the language, so the concept of speaking for the people of Sasak, not only lies in the truth of the word in a sentence structure, but it must also be supported by a proper sentence, in conjunction with how to keep the feeling of people in speaking.

Thus the importance of keeping the other person's feelings for the people of Sasak, resulting in a term known perajong base language that has meaning in the language ability of a speaker while maintaining politeness which include low self-esteem and attitude while maintaining the feelings of others.

In connection with that, in the Sasak language use, should pay attention to ethics and values sense of language in the form of: a) Bans tones that are offending others; dan b) Bans tone commands in the language.

Consider the following example sentences:

Mamiq lamun pelungguh margi Sakra, tumbasang tiang tangkong (Sir, if you go to Sakra, buy me clothes)

If you notice, the sentence above has met the truth structure that is characterized by the precision placement of the form soft language (margi and tumbas), as a marker of the work will be done by pelungguh and tiang and use of tangkong which marks for yourself but the sentence can not be justified in the use of Soft Sasak language, because the sentence contains the tone of command.

Because in the Sasak language level is not justified any form of sentences that are suggestive commands so tense in this language level hanay justify a sentence with an invitation tone, expectations and demands.

Comparing example above sentence with the sentences below:

Mamiq lamun pelungguh margi Sakra, tiang ngelungsur tangkong gamaq sekeq, (Sir, if you go to Sakra, I ask for help, buy me a shirt)

If the note form of the sentence above, contains the same meaning, the meaning of the second sentence only request that contains the value of the different flavors. Ngelungsur meaningful use of words requested, making Sasak language sentence can be accepted by the speaker.

However, as has been explained that a sentence can not be justified if their use is not supported by compliance with the value of speaking in public taste. Therefore, the second sentence above is considered not have a language requirement in the truth, because the second sentence worded as though challenging, so for a speaker who understands surely will try to avoid the use of sentences like the above sentence shape or the like.

\section{CONCLUSION}

Based on the above it can be concluded as follows: (a) Sasak language has a very strategic position as a communication tool and unifying role in society Sasak; (b) Besides functioning as a communication tool, Sasak language can also be used as a means of regulating society and a harmonious relationship as a filter of negative impact on the advancement of science and technology and the development of information transformation; dan (c) Sasak language usage lies in communicative language use and maintain the unity of meaning and information by sticking to the principles of language which is based on the identity of Sasak community by promoting the value of a sense of language, mutual respect, and civility in the association.

\section{REFERENCES}

Adiono, T., Irsyadi, M. S., Hidayat, Y. S., \& Irawan, A. (2009). 64-point fast efficient FFT architecture using radix-23 single path delay feedback. In 2009 International Conference on Electrical Engineering and Informatics (Vol. 2). IEEE.

Astuti, P. P. (2018). Variasi Bahasa Stiker Sepeda Motor di Kota Mojokerto Serta Relevansi dalam Pembelajaran Bahasa Indonesia di SMP. Matapena: Jurnal Keilmuan Bahasa, Sastra, dan Pengajarannya, 1 (2), 93-108. 
Giyoto, G. (2013). Pengantar Sosiolinguistik. IAIN Surakarta.

Hartanto, A., Timothy, R., Yoannita, M., \& Yoannita, M. (2014). Rancang Bangun Edugame Night At School pada Android sebagai Media Pembelajaran Siswa Sekolah Dasar.

Harmoko, D. D. (2015). Analisa Bahasa Indonesia sebagai Bahasa Komunikasi antar Negara Anggota Asean. SNIT 2015, 1 (1), 1-6.

Hastuti, H. (2016). Pengetahuan Sosiolinguistik sebagai Dasar Keterampilan Komunikasi Lisan di dalam Masyarakat. Lentera: Jurnal Ilmiah Kependidikan, 2, 247-266.

Isdianto, E. (2014). Bahasa dan Teknologi. Jurnal Bahasa, 40 (91), 90-98.

Istiqomah, N. (2017). Analisis Variasi Penggunaan Bahasa Caption di Instagram. University of Muhammadiyah Malang.

Kuswoyo, K. (2015). Pendekatan Pragmatik dalam Pembelajaran Bahasa. El-Wasathiya: Jurnal Studi Agama, 3 (2), 158-167.

Nasution, D. H. (2019). Analisis Campur Kode dan Alih Kode Bahasa Guru SD Negeri 118180 Sidonok di Lingkungan Sekolah: Tinjauan Sosiolinguistik.

Putrayasa, I. B. (2010). Penerapan Model Konstruktivisme Berpendekatan Inkuiri dalam Pembelajaran Bahasa Indonesia. In Jurnal Pendidikan dan Pengajaran (Vol. 43).

Rabiah, S. (2018). Language as a Tool for Communication and Cultural Reality Discloser.

Rohmadi, D. (2011). Pemakaian Bahasa dalam Rubrik Celathu Butet pada Surat Kabar Suara Merdeka (Suatu Tinjauan Sosiolinguistik). Universitas Sebelas Maret.

Rohmiatun, S. (2018). Connotative Meanings in Selected Song Lyrics of Creed. IAIN Surakarta.

Sandi, A. W., Rapi, M., \& Muhdy, A. A. (2018). Makna yang Terkandung dalam Karya Kaligrafi Islam Kontemporer Abd. Aziz Ahmad. Jurnal Imajinasi, 2 (2), 1-9.

Sastratmaja, H. (2013). Variasi Bahasa; Slang dan Jargon Tukang Ojek di Pangkalan Ojek Jalan Oscar Raya Bambu Apus Pamulang Tangerang Selatan Banten. IDEAS: Journal on English Language Teaching and Learning, Linguistics and Literature, 1(1).

Siandiko, D. (2018). Alih Kode dan Campur Kode Pada Komunikasi Guru dan Peserta Didik Dalam Pembelajaran Bahasa Prancis Kelas XI di SMA Negeri 9 Bandar lampung. 